\title{
Aerobic Bacteria Occurring in the Vagina of Bitches with Reproductive Disorders
}

\author{
By L. Bjurström
}

Department of Veterinary Microbiology, Section of Clinical Microbiology, Faculty of Veterinary Medicine, Swedish University of Agricultural Sciences, Uppsala, Sweden.

\begin{abstract}
Bjurström L.: Aerobic bacteria occurring in the vagina of bitches with reproductive disorders. Acta vet. scand. 1993, 34, 29-34. - A retrospective survey was performed of aerobic bacterial species found in the vagina of 203 bitches with genital disorders, e.g. infertility, vaginitis, pyometra and puppy death. Escherichia coli, beta-hemolytic streptococci, Staphylococcus intermedius and Pasteurella multocida were the species most often isolated. From bitches with pyometra $E$. coli in pure culture was the most frequent isolate. In contrast, the majority of infertile bitches gave rise to mixed cultures, and no specific bacterial species was consistently associated with infertility. Thus, bacterial sampling from infertile bitches was concluded to be of low diagnostic value. Bacterial species isolated from the bitches having vaginitis were present in pure culture in $26.9 \%$ of the samples while nonspecific mixed cultures were obtained from $34.6 \%$ of the samples from these bitches. $E$. coli was the most frequently isolated bacterial species from bitches with dead puppies. However, in such cases it is important to relate the vaginal bacterial findings to autopsy findings and the results of bacteriological cultures of the pups.
\end{abstract}

dog.

\section{Introduction}

Bacteriological examination of vaginal samples from bitches is often made in an attempt to identify the etiologic agents associated with infertility, vaginitis and puppy death (Osbaldiston 1971, Okkens et al. 1977, Osbaldiston 1978, Linde 1978, Stockner et al. 1979, Farstad 1982, Linde 1983, Bulgin et al. 1984).

Proper interpretation of the bacteriological results requires that the clinical history of the bitches be known since bacterial species isolated from bitches with reproductive disorders can also be found in vaginal samples from normal bitches (Osbaldiston et al. 1972, Platt \& Simpson 1974, Hirsh \& Wiger 1977, Doig et al. 1981, Allen \& Dagnall 1982, Blunden 1983, Skaar 1989).

The purpose of this study was to make a retro- spective survey of aerobic bacterial species found in the vagina of bitches with genital disorders such as infertility, vaginitis, pyometra and puppy death, in order to study whether any particular bacterial species are consistently associated with specific disorders.

\section{Materials and methods}

Results of bacterial examinations of vaginal samples from 203 bitches with reproductive disorders were analysed. The samples had been examined at the Department of Veterinary Microbiology at the Swedish University of Agricultural Sciences. A variety of reproductive disorders had been clinically diagnosed among the bitches, which were patients at the Small Animal Clinic, Veterinary Faculty, Swedish Univer- 
sity of Agricultural Sciences. The bitches were selected on the basis of the diagnosis stated on the referrals of the samples and were divided into 4 groups: Group 1: 42 bitches with fertility problems (failure to conceive), without signs of clinical infection; Group 2: 78 bitches with a discharge from the vulva, diagnosed as having vaginitis; Group 3: 71 bitches with pyometra; and Group 4: 12 bitches experiencing puppy deaths. Vaginal bacterial samples were obtained through a vaginal speculum with a sterile cotton swab. The swabs were streaked onto agar plates between 1 and $24 \mathrm{~h}$ after collection. Routine procedures for bacteriological examination of vaginal swabs included inoculation on $7 \%$ horse blood (v/v) agar and bromcresolpurpur-lactose agar followed by incubation at $37^{\circ} \mathrm{C}$ for 24 and $48 \mathrm{~h}$. Bacteria were identified according to Bergey's Manual of Systematic Bacteriology (Holt 1984). Bacterial findings were considered to be of significance when a moderate to profuse growth of a single species occurred. Mixed cultures were considered to be of significance only when 1 or 2 of the bacterial species grew profusely and dominated on the plate. When more than 2 species grew on the plate it was defined as a nonspecific mixed culture. Statistical evaluations were made using a Chisquare test and Fisher's exact test.

\section{Results}

The bacterial species found in the 4 different groups of bitches are presented in Table 1. Escherichia coli, beta-hemolytic streptococci, Staphylococcus intermedius and Pasteurella multocida were the species most frequently isolated.

$E$. coli was isolated significantly more often from bitches with pyometra than from bitches with vaginitis $(\mathrm{p}<0.05)$ and more frequently from bitches with vaginitis than from infertile bitches $(\mathrm{p}<0.05)$. E. coli was also the most frequently isolated bacterial species $(41.7 \%)$ in the 12 bitches who had delivered dead puppies or whose puppies had died soon after birth.

Beta-hemolytic streptococci were isolated more frequently from infertile bitches than from bitches with vaginitis $(\mathrm{p}<0.05)$.

The incidence of $S$. intermedius did not vary significantly between the groups.

P. multocida was isolated significantly more often in samples from the infertile bitches than in samples from bitches with pyometra and vaginitis $(\mathrm{p}<0.05)$.

The number of bacterial species isolated per sample and the various bacteria found in pure cultures from bitches are presented for each group in Figs. 1-4. In bitches with fertility problems, the frequency of nonspecific mixed cultures was high [23 (54.8\%) of the bitches]. For bitches with vag-

Table 1. Bacterial findings from the vaginas of 203 bitches with different reproductive disorders.

\begin{tabular}{|c|c|c|c|c|}
\hline Bacterial species & $\begin{array}{c}\frac{\text { Infertility }}{n=42} \\
\text { Bitches \% }\end{array}$ & $\begin{array}{c}\text { Vaginitis } \\
\mathrm{n}=78 \\
\text { Bitches \% }\end{array}$ & $\begin{array}{c}\text { Pyometra } \\
\mathrm{n}=71 \\
\text { Bitches \% }\end{array}$ & $\begin{array}{c}\text { Puppy death } \\
\mathrm{n}=12 \\
\text { Bitches } \%\end{array}$ \\
\hline Escherichia coli & 14.3 & 32.1 & 50.7 & 41.7 \\
\hline Beta-hemolytic streptococci & 38.1 & 19.2 & 28.2 & 16.7 \\
\hline Staphylococcus intermedius & 9.5 & 12.8 & 5.6 & 8.3 \\
\hline Pasteurella multocida & 21.4 & 6.4 & 5.6 & - \\
\hline Proteus mirabilis & 7.1 & 6.4 & 4.2 & 8.3 \\
\hline Enterococci & - & 1.3 & - & - \\
\hline Alfa-hemolytic streptococci & 4.8 & - & - & - \\
\hline No bacterial growth & 14.3 & 25.6 & 11.3 & 16.7 \\
\hline
\end{tabular}




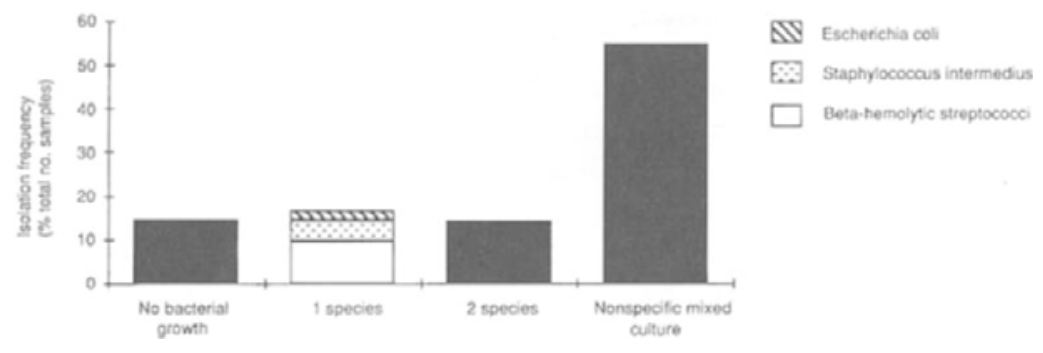

Figure 1. Frequency distribution of the number of bacterial species/sample in infertile bitches $(n=42)$.

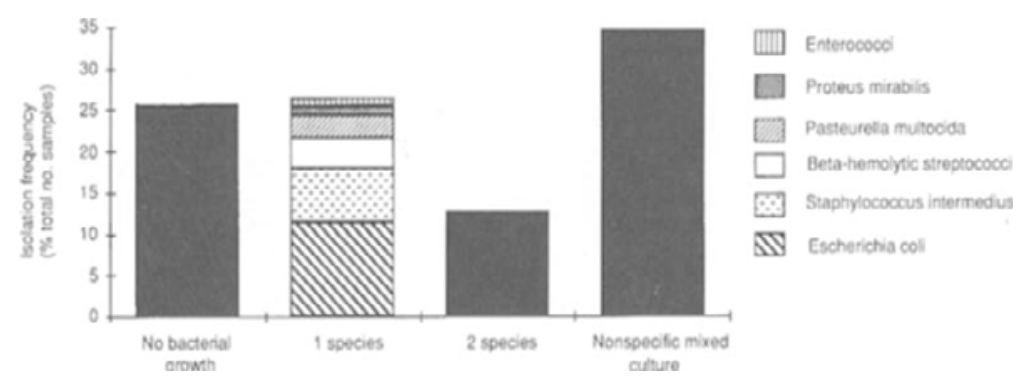

Figure 2. Frequency distribution of the number of bacterial species/sample in bitches with vaginitis $(n=78)$.

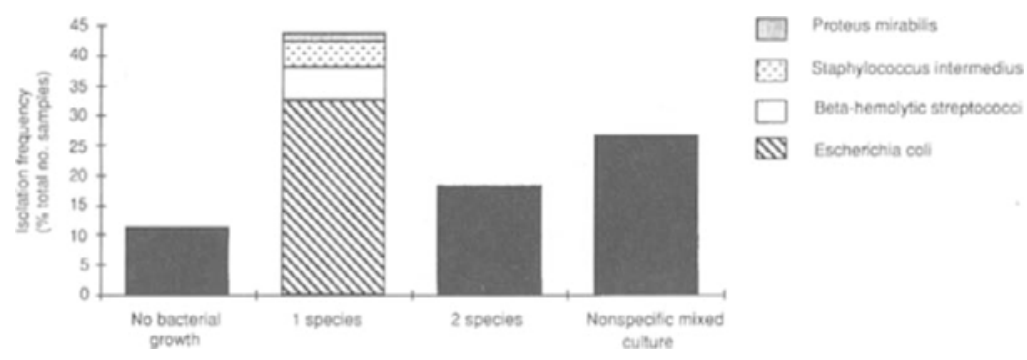

Figure 3. Frequency distribution of the number of bacterial species/sample in bitches with pyometra $(n=71)$.

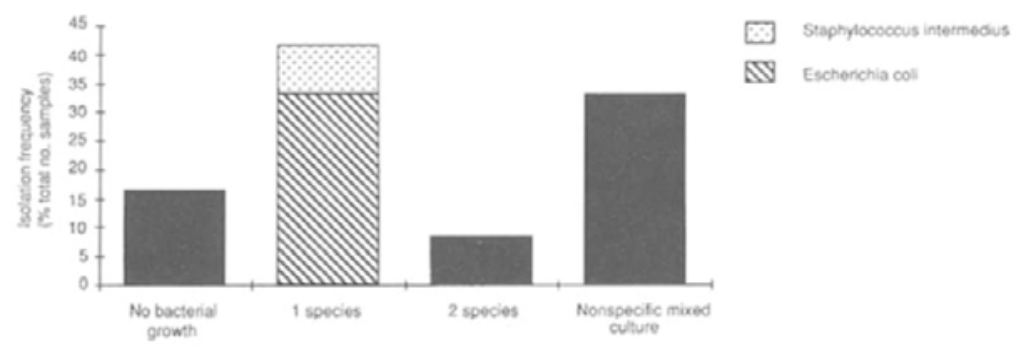

Figure 4. Frequency distribution of the number of bacterial species/sample in bitches with dead puppies $(n=12)$. 
initis, culturing did not result in any growth of bacteria for 20 samples $(25.6 \%)$, while nonspecific mixed cultures were obtained from 27(34.6\%) (Fig. 2). Pure cultures were isolated more frequently from bitches with pyometra than from bitches with vaginitis $(\mathrm{p}<0.05)$ and from those with fertility problems $(p<0.01)$. Of the bitches who had dead puppies $5(41.7 \%$ ) yielded pure cultures and $4(33.3 \%)$ yielded nonspecific mixed cultures.

\section{Discussion}

The bacterial species most frequently isolated from the vagina of bitches with genital disease were $E$. coli, beta-hemolytic streptococci, $S$. intermedius and $P$. multocida, in accordance with studies by Farstad (1982) and Skaar (1989). Bacteriological samples of bitches with fertility problems mostly yielded nonspecific mixed cultures. The significantly higher $(\mathrm{p}<0.05)$ frequency of $P$. multocida and beta-hemolytic streptococci in bitches with fertility problems, compared with the other groups, can be ascribed to the fact that the majority of the former bitches were sampled during oestrus, when these bacterial species are commonly found in bitches with as well as without reproductive disorders (Allen \& Dagnall 1982, Farstad 1982, Bjurström \& Linde-Forsberg 1992). Osbaldiston (1972) found that bitches with fertility problems and those with normal fertility had a similar bacterial flora. In the present study, infertility could not be associated with any specific bacterial species. According to the results of the present investigation, bacterial sampling from the vagina of infertile bitches without any clinical signs of genital infection is of low diagnostic value.

E. coli, S. intermedius and beta-hemolytic streptococci were the species most frequently isolated in pure culture from bitches with vaginitis. This is in accordance with studies by Hirsh \& Wiger (1977). They also compared normal bitches with bitches having vaginitis; although the 2 groups hosted the same bacterial species, samples from bitches with vaginitis tended to have fewer species and a higher number of bacteria than samples from normal bitches. In the present study mixed cultures were frequently obtained. In agreement with the opinion of Hirsh \& Wiger (1977) it is plausible that bacterial species isolated from a bitch having vaginitis should be present in pure culture or 2-species mixed cultures to be regarded as of significance. For bitches where samples resulted in more than 2 bacterial species, other reasons than a bacterial infection causing the vaginitis should be considered, such as anatomic abnormalities, urinary tract infection, neoplasia, foreign bodies or Herpes virus infection (Burke 1986).

The dominance of $E$. coli in bitches with pyometra in the present study is in agreement with previous findings (Grindlay et al. 1973, Sandholm et al. 1975, Farstad 1982). In the present study, samples were taken from the vagina rather than from the uterus, which could explain the high frequency of mixed cultures.

Farstad (1983) found that bacterial infection was the most common cause of death among autopsied pups (61\%). Mixed infections with $S$. intermedius and E. coli dominated. However, Suter (1977) found that bacterial infection was the cause of death in only $22.2 \%$ of autopsied pups. E. coli was the species most often isolated. These bacterial findings are in accordance with those of the present study. Thus, when diagnosing puppy deaths, it is important to consider the bacterial findings from the bitch along with autopsy findings and results from the bacteriological examination of the pups.

Except in the pyometra group, the incidence of bacteriologically negative samples was high compared with earlier reports (Hirsh \& Wiger 1977, Osbaldiston 1978, Farstad 1982). This difference could partly be due to the culturing 
methods used in the present study; e.g., neither anaerobic culturing nor other specific methods were used (Bruchim \& Lutsky 1978, Ling \& Ruby 1978, Osbaldiston 1978, Doig et al. 1981, Farstad 1982, Baba et al. 1983, Blunden 1983, Gentilini \& Denamiel 1983).

\section{Conclusion}

According to the present survey it is concluded that examination of bitches with reproductive disorders for aerobic bacteria is of limited value in dogs with infertility problems and vaginitis. In bitches with pyometra and puppy death there was, however, a rather high frequency of cases with mainly $E$. coli in pure culture.

\section{References}

Allen WE, Dagnall GJR: Some observations on the aerobic bacterial flora of the genital tract of the dog and bitch. J. small Anim. Pract. 1982, 23, 325-335.

Baba E, Hata H, Fukata T, Arakawa A: Vaginal and uterine microflora of adult dogs. Amer. J. vet. Res. 1983, 44, 606-609.

Bjurström L, Linde-Forsberg C: A long-term study of aerobic bacteria of the genital tract in breeding bitches. Amer. J. vet. Res. 1992, 53, 665-669.

Blunden AS: Isolation of Clostridium perfringens from the canine genital tract. Vet. Rec. 1983, 113, 133.

Bruchim A, Lutsky I: Isolation of mycoplasma from the canine genital tract: a survey of 108 healthy dogs. Res. vet. Sci. 1978, 25, 243-245.

Bulgin MS, Ward ACS, Sriranganathan N, Saras P: Abortion in the dog due to Campylobacter species. Amer. J. vet. Res. 1984, 45, 555-556.

Burke TJ: Causes of infertility. In: Burke TJ (Ed.): Small Animal Reproduction and Infertility. A Clinical Approach to Diagnosis and Treatment. Lea \& Febiger, Philadelphia, 1986, 227-297.

Doig PA, Ruhnke HL, Bosu WTK: The genital Mycoplasma and Ureaplasma flora of healthy and diseased dogs. Can. J. comp. Med. 1981, 45, 233-238.

Farstad W: Bakteriologiske funn i kjönnsveiene hos tisper med reproduktionsforstyrrelser. (Bacterial findings in the genital tract of bitches with reproductive disorders). Nord. Vet.-Med. 1982, 34, 451456.

Farstad W: Perinatal valpdödlighet hos hund II: Frekvens og patoanatomiske funn. (Perinatal puppy death in the dog II. Mortality rate and pathoanatomical findings.) Norsk. Vet. Tidsskr. 1983, 95, 567-572.

Gentilini ER, Denamiel GA: Mesophilic vaginal flora of bitches. I. Bacteriological findings. Gac. Vet. (B. Aires) 1983, 383, 910-913.

Grindlay M, Renton JP, Ramsay DH: O-groups of Escherichia coli associated with canine pyometra. Res. vet. Sci. 1973, 14, 75-77.

Hirsh DC, Wiger N: The bacterial flora of normal canine vagina compared with that of vaginal exudates. J. Small Anim. Pract. 1977, 18, 25-30.

Holt JG: Bergey's Manual of Systematic Bacteriology. Williams \& Wilkins Co. Baltimore, 1984, 1986, Vol $1 \& 2,1599 p p$.

Linde C: Genitala infektioner hos hund. (Genital infections in the dog). Kompendium till allmänt veterinärmöte. Sv. Vet.-Förb., Stockholm, 1978, 3846.

Linde C: Partial abortion associated with genital Escherichia coli infection in a bitch. Vet. Rec. 1983, 112, 454-455.

Ling GV, Ruby AL: Aerobic bacterial flora of the prepuce, urethra, and vagina of normal adult dogs. Amer. J. vet. Res. 1978, 39, 695-698.

Okkens AC, GunninkJW, VogelF, Van der Weyden GC: Vaginitis bij de teef. (Vaginitis in the bitch). Tijdschr. Diergeneesk. 1977, 102, 1034-1038.

Osbaldiston GW: Vaginitis in a bitch associated with Haemophilus sp. Amer. J. vet. Res. 1971, 42, 20672069.

Osbaldiston GW, Nuru S. Mosier JE: Vaginal cytology and microflora of infertile bitches. J. Amer. Anim. Hosp. Assoc. 1972, 8, 93-101.

Osbaldiston GW: Bacteriological studies of reproductive disorders of bitches. J. Amer. Anim. Hosp. Assoc. 1978, 14, 363-367.

Platt AM, Simpson RB: Bacterial flora of the canine vagina. Southwest. Vet. 1974, 27, 76-77.

Sandholm M, Vasenius H, Kivistö AK: Pathogenesis of canine pyometra. J. Amer. vet. med. Assoc. 1975, 167, 1006-1010.

Skaar I: Bakteriologiska undersökelser av kjönnsvei hos tispe. (Bacteriological examinations of the reproductive tract of bitches). Norsk. Vet. Tidsskr. 1989, 101, 849-853.

Stockner PK, Brudvik AM, Baker D: Canine vaginal flora: A technique for sampling and clinical observation. Can. practit. 1979, 6, 18-22.

Suter M: Peri- und postnatale todesursachen beim hund. (Peri and post natal causes of death in dogs). Inaugural-Dissertation. Zurich, 1977. 


\section{Sammanfattning}

Aeroba bakterier förekommande $i$ vagina på tikar med reproduktionssjukdomar.

En retrospektiv studie gjordes på förekomst av aeroba bakteriearter i vagina hos 203 tikar med olika genitala sjukdomar; infertilitet, vaginit, pyometra, och valpdöd. Escherichia coli, beta-hemolyserande streptokocker, Staphylococcus intermedius och Pasteurella multocida var de bakteriearter som oftast isolerades. Från tikar med pyometra isolerades oftast $E$. coli i renkultur. Däremot kunde ingen specifik bakterieart sättas i samband med infertilitet utan blandflora isolerades från majoriteten av proverna från infertila tikar. Bakterieprover tagna från infertila tikar utan kliniska symtom har således liten eller ingen praktisk användning. Från tikar med vaginit isolerades renkultur i $26.9 \%$ av proverna medan blandflora erhölls från $34.6 \%$ av proverna. Den bakterieart som oftast isolerades i renkultur från tikar med valpdöd var E.coli. Vid tolkning av ett vaginalt bakterieprov isolerat från tikar med döda valpar är det viktigt att korrelera bakteriefynden med obducerade och bakteriologiskt undersökta valpar.

(Received October 6, 1992; accepted October 9, 1992).

Reprints may be requested from: L. Bjurström, Department of Veterinary Microbiology, Section of Clinical Microbiology, Faculty of Veterinary Medicine, Swedish University of Agricultural Sciences, P.O. Box 7073, S-750 07 Uppsala, Sweden. 